\title{
ANALISIS KUALITAS INFORMASI AKUNTANSI TERHADAP AKUNTABILITAS INTERNAL, EVALUASI KINERJA KEUANGAN, DAN PENGAMBILAN KEPUTUSAN KEUANGAN PADA BADAN PENDIDIKAN DAN PELATIHAN KEUANGAN
}

\author{
Mikha Andri Manalu ${ }^{1)}$, Acwin Hendra Saputra ${ }^{2) *}$ \\ Badan Pendidikan dan Pelatihan Keuangan \\ email: mikha.pku@gmail.com \\ Jurusan Manajmen Keuangan, Politeknik Keuangan Negara STAN \\ email: acwin@pknstan.ac.id
}

\begin{abstract}
This study aims to determine the effect of the quality of accounting information on internal accountability, financial performance evaluation, and financial decision making in work units within the BPPK. The total number of respondents in this study were 116 people. This research uses quantitative methods with causal relationships and inferential analysis, and the type of data produced is primary data. The results of the study conclude that the quality of accounting information has a significant positive relationship with internal accountability at the BPPK, the quality of accounting information has a significant positive relationship with the BPPK's financial performance evaluation, the quality of accounting information has a significant positive relationship with financial decision making at the BPPK. The quality of BPPK accounting information has a high and unidirectional correlation with internal accountability, moderate and unidirectional correlation with financial performance evaluation, and moderate and unidirectional correlation with financial decision making.
\end{abstract}

Keywords: information quality, internal accountability, financial performance evaluation, decision making

\begin{abstract}
ABSTRAK
Penelitian ini bertujuan untuk mengetahui pengaruh kualitas informasi akuntansi terhadap akuntabilitas internal, evaluasi kinerja keuangan, dan pengambilan keputusan keuangan pada satuan kerja di lingkungan BPPK. Jumlah total responden dalam penelitian ini sebanyak 116 orang. Penelitian ini menggunakan metode kuantitatif dengan hubungan kausal dan analisis inferensial, dan jenis data yang dihasilkan adalah data primer. Hasil penelitian menyimpulkan bahwa kualitas informasi akuntansi berhubungan positif signifikan dengan akuntabilitas internal pada BPPK, kualitas informasi akuntansi berhubungan positif signifikan dengan evaluasi kinerja keuangan BPPK, kualitas informasi akuntansi berhubungan positif signifikan dengan pengambilan keputusan keuangan pada BPPK. Kualitas informasi akuntansi BPPK memiliki hubungan korelasi tinggi dan searah dengan akutabilitas internal, korelasi sedang dan searah dengan evaluasi kinerja keuangan, dan tingkat korelasi sedang dan searah dengan pengambilan keputusan keuangan.
\end{abstract}

Kata Kunci: kualitas informasi, akuntabilitas internal, evaluasi kinerja Keuangan, pengambilan keputusan 


\section{PENDAHULAN}

Laporan keuangan secara umum bertujuan untuk memberikan informasi tentang kondisi keuangan suatu entitas pada periode tertentu. International Pubic Sector Accounting Standard (IPSAS) menyatakan laporan keuangan bertujuan memberikan informasi posisi keuangan, kinerja keuangan dan arus kas suatu entitas yang dapat dimanfaatkan oleh pengguna dalam mengambil dan mengevaluasi keputusan, serta menunjukkan akuntabilitas entitas atas pengelolaan sumber daya yang dimiliki. Akan tetapi, angka yang terdapat dalam laporan keuangan belum menjadi informasi dan tetap hanya berupa data apabila deretan angka tersebut tidak memberikan makna atau nilai bagi pembacanya (Suwardjono, 2013). Untuk itu, entitas akuntansi harus memiliki kredibilitas yang diwujudkan melalui transparansi dan profesionalitas yang ditampilkan dalam laporan keuangan yang dikerjakan sesuai dengan standar yang berlaku (Standar Akuntansi Pemerintah). Karena apabila laporan tidak sesuai dengan standar yang berlaku akan mengakibatkan rendahnya keandalan dan objektivitas informasi yang terkandung didalamnya (Mardiasmo, 2009).

Salah satu tujuan penyusunan laporan keuangan sesuai dengan SAP adalah untuk memperoleh opini Wajar Tanpa Pengecualian (WTP) dari Badan Pemeriksa Keuangan (BPK). Namun dalam pelaksanaan praktek akuntansi pemerintah yang sudah berusia 12 tahun sejak 2004, Laporan Keuangan Pemerintah Pusat (LKPP) yang dihasilkan baru memperoleh opini WTP untuk pelaporan tahun anggaran 2016. Penyusunan dan penyajian laporan keuangan yang sesuai standar membutuhkan keahlian dan kompetensi di bidang keuangan negara yang dapat diperoleh melalui pendidikan dan pelatihan. Badan Pendidikan dan Pelatihan Keuangan (BPPK) sebagai salah satu unit eselon I di lingkungan Kementerian Keuangan yang sudah memiliki opini laporan keuangan WTP merupakan pionir dalam pelaksanaan/implementasi akuntansi berbasis akrual, dan penyelenggara program diklat percepatan akuntabilitas pemerintah. Sebagai instansi yang memiliki kualitas laporan keuangan, sumber daya manusia, dan pengetahuan teknologi informasi yang baik, penulis ingin melihat apakah laporan keuangan yang disusun sesuai dengan tujuan penggunaan laporan keuangan. Penelitian ini bertujuan untuk mengetahui pengaruh kualitas informasi akuntansi terhadap akuntabilitas internal, evaluasi kinerja keuangan, dan pengambilan keputusan keuangan pada Badan Pendidikan dan Pelatihan Keuangan.

\section{KAJIAN LITERATUR}

Teori agensi menunjukkan variabel kontrol atas manajemen secara tepat, dan menentukan elemen kontrol optimal yang bisa dibentuk dalam berbagai kondisi/situasi, serta mempertimbangkan perilaku dan motivasi yang dibangun dalam mekanisme kontrol (Namazi, 2013). Sehingga agen dapat melaksanakan kegiatan dengan maksimal dan terarah. Pada sektor publik, yang dimaksud dengan principal adalah lembaga legislatif yang mewakili rakyat, sedangkan agen merupakan lembaga eksekutif yaitu pemerintah yang melaksanakan pengelolaan atas sumber daya yang ditujukan untuk meningkatkan kesejahteraan masyarakat (Halim dan Abdullah, 2006). Selain hubungan antara pemerintah dengan rakyat, teori keagenan juga mengatur hubungan antara pemerintah (principal) yang menyusun komite untuk menetapkan standar dalam upaya mewujudkan akuntabilitas dan transparansi terhadap instansi/satuan kerja (agen) di bawahnya

Teori entitas muncul karena adanya kebutuhan mendesak dalam melaksanakan transformasi atas kebijakan akuntansi dan inovasi yang dibutuhkan untuk memperoleh analisis informasi yang 
mendalam. Sehingga teori entitas dapat diartikan sebagai teori ekonomi pada suatu organisasi (perusahaan) yang mengacu pada suatu konsep skenario ekonomi baru di mana akuntansi menggunakan berbagai pertimbangan ekonomi dan basis akuntansi sesuai dengan kebutuhan organisasi (Zanoni, 2000). Hal ini berkaitan dengan perubahan basisakuntansi yang digunakan pemerintah sejak tahun 2004 hingga 2015 yaitu basis kas, cash toward acrual, dan akrual.

Romney dan Steinbart (2015) menyatakan "informasi adalah data yang telah dikelola dan diproses untuk memberikan arti dan memperluas pengambilan keputusan, sehingga keputusan pengguna lebih baik dengan kuantitas dan kualitas peningkatan informasi". Di mana laporan keuangan merupakan suatu informasi yang menggambarkan kondisi keuangan suatu perusahaan, dan informasi tersebut dapat dikembangkan sebagai gambaran kinerja keuangan suatu entitas (Fahmi, 2011). Sehingga dapat dinyatakan bahwa laporan keuangan sektor publik merupakan komponen penting untuk menciptakan akuntabilitas pemerintah di mata masyarakat (Mardiasmo, 2009). Sedangkan Bastian (2010) menyatakan laporan keuangan merupakan cerminan dari posisi keuangan serta transaksitransaksi yang telah dilakukan suatu organisasi sektor publik dalam kurun waktu tertentu. Hal tersebut didukung oleh Riswan dan Yolanda (2014) yang menyatakan laporan keuangan sebagai catatan informasi keuangan suatu perusahaan pada suatu periode akuntansi yang dapat digunakan untuk menggambarkan kinerja perusahaan.

Akuntabilitas pada Lampiran I kerangka konseptual (SAP) paragraf 25 disampaikan sebagai bentuk pertanggungjawaban pengelolaan sumber daya serta pelaksanaan kebijakan yang dipercayakan kepada entitas pelaporan dalam mencapai tujuan yang telah ditetapkan secara periodik. Akuntabilitas dapat mengatasi timbulnya kekuasaan yang bersifat tirani, oleh sebab itu harus ada landasan moral atas kekuasaan, ada batasan terhadap kekuasaan, dan petanggungjawaban dalam melaksanakan kekuasaan (Standbury, 2003). Untuk memastikan pemerintahan yang lebih baik, maka akuntabilitas harus ditingkatkan baik melalui sistem integritas, pengendalian internal, maupun kepemimpinan, sehingga dapat membantu pembuat kebijakan dalam menyemangati lingkungan pertanggungjawaban pada instansi pemerintah (Aziz et al., 2015).

Hal ini bermanfaat untuk membantu pengambil keputusan dalam memonitor dan memperbaiki kinerja serta berfokus pada tujuan organisasi dalam memenuhi tuntutan akuntabilitas publik. Menurut Munawir (2010) evaluasi atas kinerja keuangan perusahaan merupakan satu diantara dasar penilaian mengenai kondisi keuangan perusahaan yang dilakukan berdasarkan analisa terhadap rasio keuangan perusahaan. Maka untuk meningkatkan kinerja dalam rangka mencapai tujuan yang telah ditetapkan oleh pengambil keputusan, evaluasi/pengukuran harus dilaksanakan setiap periode pelaporan keuangan terutama atas perencanaan dan pelaksanaan anggaran yang telah terjadi.

PSAP 01 paragraf 9 menyatakan tujuan umum menyajikan informasi mengenai transaksi keuangan dan kegiatan operasional suatu entitas pelaporan harus bermanfaat bagi para pengguna sehingga dapat membuat keputusan yang lebih baik dan dapat mengevaluasi keputusan atas penggunaan sumber daya. Maka untuk mencapai tujuan tersebut laporan keuangan harus transparan dan dipublikasikan kepada masyarakat. Selain itu, banyak persoalan yang membutuhkan penyelesaian yang cepat dan tepat, sehingga perlu dikumpulkan berbagai bahan informasi supaya proses pengambilan keputusan dapat 
menghasilkan solusi yang terbaik atas permasalahan yang dihadapi (Harahap, 2013).

Hasil penelitian dari Wakhid Susilo dan Rusdi Akbar (2015) bertujuan untuk mengetahui seberapa besar pengaruh kualitas informasi akuntansi terhadap akuntabilitas internal, evaluasi kinerja keuangan, dan pengambilan keputusan keuangan. Serta lebih jauh lagi untuk mengetahui kenapa peningkatan kualitas informasi berpengaruh terhadap peningkatan penggunaan informasi akuntansi dan mengapa informasi akuntansi belum dimanfaatkan secara optimal oleh pengguna.

Berdasarkan uraian sebelumnya, kerangka pemikiran yang digunakan untuk merumuskan hipotesis adalah sebagai berikut:

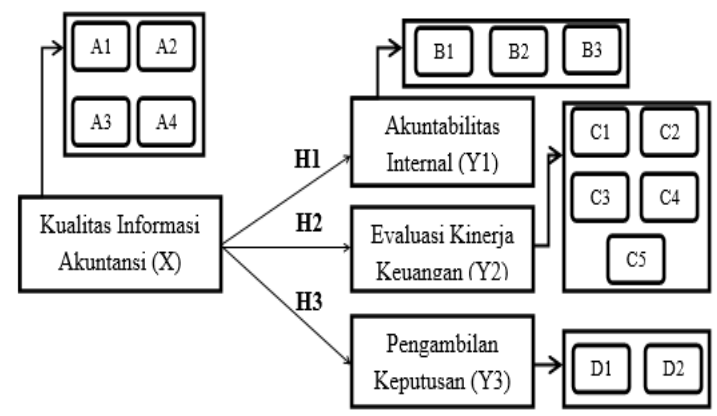

Gambar 1. Kerangka Pemikiran

Hipotesis merupakanjawaban sementara terhadap masalah yang bersifat praduga karena masih harus diuji kebenarannya (Bakri, 2020). Hipotesis dalam penelitian ini adalah:

H1: Terdapat hubungan positif signifikan antara informasi akuntansi dengan akuntabilitas internal pada BPPK.

$\mathrm{H} 2$ : Terdapat hubungan positif signifikan antara informasi akuntansi dengan evaluasi kinerja keuangan pada BPPK.

H3: Terdapat hubungan positif signifikan antara informasi akuntansi dengan pengambilan keputusan keuangan pada BPPK.

\section{METODE PENELITIAN}

Penelitian ini menggunakan metode kuantitatif dengan hubungan kausal dan analisis inferensial, dengan jenis data yang digunakan adalah data primer. Dengan kualitas informasi akuntansi variable independen dan akuntabilitas internal, evaluasi kinerja keuangan, dan pengambilan keputusan keuangan sebagai variabel dependen. Di mana data yang diperoleh langsung dari sumber data pertama atau tangan pertama di lapangan. Pengumpulan data dilakukan melalui kuesioner dengan menggunakan skala likert. Kuesioner digunakan untuk mengetahui faktor apa saja yang dipengaruhi oleh kualitas informasi akuntansi pada satuan kerja di lingkungan BPPK.

Populasi penelitian merupakan pejabat/pengelola keuangan di lingkungan BPPK. Dan dengan memperkirakan bahwa hubungan antara variabel merupakan hubungan yang cukup erat, maka dengan menggunakan tabel sampel Isac dan Michael (Sugiyono, 2016) diperoleh ukuran sampel sebanyak 110 responden yang bertugas melaksanakan penyusunan laporan keuangan.

Pengumpulan data kuantitatif menggunakan metode kuesioner dengan skala likert 5 poin. Instrumen kuesioner yang digunakan dalam penelitian ini sebagian besar disusun dari penelitian Susilo dan Rusdi dan ditambahkan beberapa instrumen dari penelitian lain. Pembagian kuesioner dilakukan melalui 2 cara. Pertama, kuesioner dalam bentuk softcopy dan dalam bentuk hardcopy. Jangka waktu pengisian kuesioner adalah sejak kuesioner dikirimkan pada tanggal 21 Mei 2017 s.d. 2 Juni 2017 dan telah terkumpul 116 buah. 
4 HASIL DAN PEMBAHASAN

Uji Reliabilitas Dan Uji Validitas

Tabel 1 Hasil Uji Reliabilitas Tiap

Variabel

\begin{tabular}{|l|c|}
\hline \multicolumn{1}{|c|}{ Variabel } & $\begin{array}{c}\text { Nilai Cronbach's } \\
\text { Alpha }\end{array}$ \\
\hline \hline $\begin{array}{l}\text { Kualitas Informasi } \\
\text { Akuntansi }\end{array}$ & 0,926 \\
\hline $\begin{array}{l}\text { Akuntabilitas } \\
\text { Internal }\end{array}$ & 0,906 \\
\hline $\begin{array}{l}\text { Evaluasi Kinerja } \\
\text { Keuangan }\end{array}$ & 0,938 \\
\hline $\begin{array}{l}\text { Pengambilan } \\
\text { Keputusan } \\
\text { Keuangan }\end{array}$ & 0,894 \\
\hline
\end{tabular}

Hasil uji validitas menunjukkan nilai $r$ hitung lebih besar daripada $\mathrm{r}$ pearson product moment sebesar 0,1576. Dimana variable kualitas informasi akuntansi memperoleh nilai $\mathrm{r}$ hitung antara 0,467 sampai dengan 0,665 , variable akuntabilitas internal memperoleh nilai $\mathrm{r}$ hitung antara 0,499 sampai dengan 0,753. Variable evaluasi kinerja keuangan memperoleh $\mathrm{r}$ hitung antara 0,554 sampai dengan 0,764 , dan pengambilan keputusan keuangan memperoleh $r$ hitung antara 0,533 sampai dengan 0,774. Sehingga semua pertanyaan dalam kuesioner dinyatakan valid. Oleh karena itu, seluruh variabel dalam penelitian ini dapat dikatakan mempunyai reliabilitas yang baik. Bahkan hanya variabel pengambilan keputusan keuangan yang memiliki nilai Cronbach's Alpha di bawah 0,90.

Tabel 2 Hasil Uji Reliabilitas Tiap Variabel

\begin{tabular}{|l|c|}
\hline \multicolumn{1}{|c|}{ Variabel } & $\begin{array}{c}\text { Nilai } \\
\text { Cronbach's } \\
\text { Alpha }\end{array}$ \\
\hline \hline $\begin{array}{l}\text { Kualitas Informasi } \\
\text { Akuntansi }\end{array}$ & 0,926 \\
\hline Akuntabilitas Internal & 0,906 \\
\hline Evaluasi Kinerja & 0,938 \\
\hline
\end{tabular}

\begin{tabular}{|l|c|} 
Keuangan & \\
\hline $\begin{array}{l}\text { Pengambilan Keputusan } \\
\text { Keuangan }\end{array}$ & 0,894 \\
\hline
\end{tabular}

\section{Uji Asumsi Klasik}

Hasil uji asumsi klasik menyatakan bahwa data yang diperoleh sudah tersebar secara normal dan tidak terjadi kesamaan varian (tidak terjadi heteroskedastisitas), dan terdapat hubungan yang linear serta kuat dan searah antara variable independen dan dependen. Dengan hasil perhitungan koefisien determinasi ( $\mathrm{R}$ square atau $\mathrm{R}^{2}$ ) menunjukkan bahwa kualitas informasi akuntansi dapat menjelaskan akuntabilitas internal oleh sebesar $62,7 \%$, evaluasi kinerja keuangan sebesar $23,1 \%$, dan pengambilan keputusan keuangan sebesar $34,8 \%$ sedangkan sisanya dipengaruhi oleh faktor lain.

\section{Uji Hipotesis}

Hasil uji regresi linear sederhana menyatakan bahwa kualitas informasi akuntansi pada Badan Pendidikan dan Pelatihan Keuangan berpengaruh positif terhadap akuntabilitas internal, evaluasi kinerja keuangan dan pengambilan keputusan. Sedangkan melalui uji $t$ diperoleh nilai $\mathrm{t}$ hitung untuk variabel akuntabilitas internal sebesar 13,481, variabel evaluasi kinerja keuangan sebesar 5,692, dan variabel pengambilan keputusan keuangan sebesar 7,589. Nilai t hitung seluruh variabel lebih besar dari nilai $t$ tabel yaitu 1,65936 . Sehingga dapat disimpulkan variabel independen berpengaruh positif signifikan terhadap variabel dependen.

\section{Kualitas Informasi Akuntansi Pada BPPK}

Berdasarkan hasil penelitian dan analisis yang dilakukan, dapat diketahui bahwa seluruh karakteristik kualitatif pada laporan keuangan telah dipenuhi oleh satuan kerja di lingkungan Badan Pendidikan dan Pelatihan Keuangan. Informasi yang tersedia telah dikelola dan 
diproses untuk memberikan arti dan meningkatkan akuntabilitas internal, evaluasi kinerja keuangan serta memperluas pengambilan keputusan, sehingga keputusan pengguna lebih baik dengan peningkatan kuantitas dan kualitas informasi yang dibuktikan dengan jawaban responden yang setuju atas kondisi laporan keuangan BPPK yang relevan, andal, dapat dipahami, dan dapat dibandingkan.

Pada kriteria relevan, BPPK telah menggunakan laporan keuangan sebagai dasar untuk melaksanakan evaluasi atas kebijakan di masa lalu, memperkirakan aktivitas keuangan di masa mendatang, menyampaikan laporan keuangan tepat waktu, serta melaksanakan penyusunan laporan keuangan sesuai dengan yang telah diatur dalam Peraturan Pemerintah Nomor 71 tahun 2010 tentang Standar Akuntansi Pemerintah. Pada kriteria andal, laporan keuangan BPPK bebas dari salah saji yang menyesatkan dan salah saji material, dibuktikan dengan Laporan Keuangan Kementerian Keuangan yang memperoleh opini WTP pada tahun 2016. Informasi telah disajikan secara jujur, dapat diverifikasi kebenarannya dan tidak bersifat memihak. Selain itu, informasi yang terdapat pada laporan keuangan sudah sesuai dengan kebutuhan, mudah dipahami, dan dapat digunakan oleh pihakpihak berkepentingan. Laporan keuangan BPPK juga telah menerapkan kebijakan yang ada secara konsisten, dan dapat dibandingkan dengan periode sebelumnya dan dengan satuan kerja sejenis.

\section{Peran Informasi Akuntansi Sebagai Alat Akuntabilitas}

Informasi akuntansi dalam laporan keuangan sangat penting untuk menunjukkan kejujuran maupun pelanggaran dalam proses pengelolaan dan pertanggungjawaban anggaran. Laporan keuangan juga dapat meningkatkan kinerja pegawai apabila laporan keuangan yang disampaikan secara dua arah dari satu bagian ke bagian lain, sehingga dapat ditemukan kelemahan dan dilakukan perbaikan. Hal yang masih harus ditingkatkan ialah aspirasi, harapan/keinginan pegawai untuk menciptakan perbaikan belum sepenuhnya dapat ditampung oleh organisasi.

Selain itu, peran serta pimpinan sebagai bagian dari akuntabilitas internal di Lingkungan BPPK sudah mencapai komitmen yang cukup kuat. Akan tetapi, belum terdapat sanksi yang jelas terhadap pegawai/satuan kerja di lingkungan BPPK yang menghasilkan laporan keuangan tidak baik. Sehingga dapat memicu adanya temuan atau penyimpangan yang menurunkan akuntabilitas organisasi. Akuntabilitas internal yang baik akan meningkatkan kualitas hubungan kerja antar pegawai, sehingga mewujudkan keterbukaan masing-masing pihak dalam organisasi untuk memperbaiki kinerja secara bersama-sama.

\section{Peran Kualitas Informasi Akuntansi Terhadap Evaluasi Kinerja Keuangan}

Salah satu analisis yang diterapkan dalam melakukan penilaian kinerja pada penelitian ini adalah analisis varian, karena merupakan analisis yang mudah dan paling banyak digunakan. Analisis varian dilakukan dengan membandingkan antara persentase realisasi belanja dengan anggaran yang tersedia, untuk menentukan penyebab tidak tercapainya realisasi belanja yang ditetapkan. Identifikasi atas masalah realisasi tersebut dapat membantu pengambilan keputusan di masa depan. Analisis lain yang dilaksanakan ialah analisis tren, walaupun sebagian besar penerapan atas analisis ini masih berupa angka.

Analisis lain yang digunakan adalah analisis common size, untuk membandingkan nilai pada masing-masing akun dengan nilai total kelompok akun. Seperti membandingkan antara nilai kas dengan total aset lancar, aset tetap dengan aset non lancar, dan sebagainya. Tujuannya untuk mengevaluasi kontribusi masing-masing akun terhadap posisi keuangan satuan kerja di lingkungan 
BPPK. Analisis lain yang tidak kalah penting ialah analisis value for money, yang diperlukan untuk menilai proses dari awal, mulai dari input, harga input hingga outcome yang diperoleh pada akhir kegiatan. Sehingga dapat disimpulkan kegiatan yang dilaksanakan selama ini apakah sudah efesien, efektif dan ekonomis.

Dalam pelaksanaan evaluasi kinerja keuangan, BPPK sudah menerapkan analisis varian, analisis tren, analisis rasio, analisis common size dan analisis velue for money, meskipun masih berfokus pada analisis atas penyerapan anggaran. Pemahaman atas berbagai macam evaluasi kinerja tersebut harus terus ditingkatkan, sehingga lebih optimal dalam penggunaannya.

\section{Pemanfaatan Kualitas Informasi Akuntansi Sebagai Alat Pengambilan Keputusan Keuangan}

Pengambilan keputusan membutuhkan informasi yang relevan dan andal. Pada penelitian ini pengambilan keputusan berfokus pada dua macam keputusan yaitu keputusan pada tahap perencanaan anggaran dan tahap pelaksanaan anggaran. Indikator yang digunakan dalam penelitian ini berkaitan dengan keputusan dalam melaksanakan investasi aset dan keputusan dalam melaksanakan belanja.

Indikator yang digunakan dalam pengambilan keputusan terkait investasi aset yaitu sehubungan dengan perencanaan kas di bendahara pengeluaran, perencanaan atas persediaan dan aset tetap/aset lainnya. Sedangkan indikator pada pengambilan keputusan belanja antara lain sehubungan dengan pelaksanaan revisi anggaran, perencanaan kebutuhan anggaran tahun berikutnya dan penetapan besaran biaya palayanan. Sebagian besar responden menjawab setuju atas indikator yang telah diajukan. Nilai rata-rata yang diperoleh pada variabel pengambilan keputusan keuangan sebesar 4,03. Dengan nilai rata-rata tertinggi 4,08 yang terdapat pada indikator perencanaan kebutuhan anggaran tahun berikutnya, dan nilai rata-rata terendah 3,94 yang terdapat pada indikator penetapan besaran biaya pelayanan.

Tabel 1. Hasil Uji Multikolinearitas Sumber: Data diolah, 2019

\section{KESIMPULAN DAN SARAN}

Berdasarkan hasil dan pembahasan yang telah dijabarkan sebelumnya, maka dapat diambil beberapa simpulan sebagai berikut:

1. Kualitas informasi akuntansi berhubungan positif signifikan dengan akuntabilitas internal pada BPPK;

2. Kualitas informasi akuntansi berhubungan positif signifikan dengan evaluasi kinerja keuangan BPPK;

3. Kualitas informasi akuntansi berhubungan positif signifikan dengan pengambilan keputusan keuangan pada BPPK.

4. Kualitas informasi akuntansi BPPK memiliki hubungan korelasi tinggi dan searah dengan akutabilitas internal, korelasi sedang dan searah dengan evaluasi kinerja keuangan, dan tingkat korelasi sedang dan searah dengan pengambilan keputusan keuangan.

\section{DAFTAR PUSTAKA}

Aziz, Mohamad Azizal Abd, Hilmi Ab Rahman, Md. Mahmudul Alam, dan Jamaliah Said. 2015. Enhancement of the Accountability of Public Sectors Through Integrity System, Internal Control System and Leadership Practice: A Review Study. International Conference on Financial Criminology. Elsavier B.V.

Bakri, B. (2020). Analisis Penerapan Akuntansi Aktiva Tetap Pada Pt Pln (Persero) Wilayah Sulsel, Sultra Dan Sulbar Area Makassar Selatan. Journal of Applied Managerial Accounting, 4(1), 2732. 
Bastian, Indra. 2010. Akuntansi Sektor Publik Edisi Ketiga (Suatu Pengantar). Jakarta: Erlangga.

Fahmi, I. 2011. Analisis Kinerja Keuangan. Cetakan Kesatu. Bandung: Alfabeta.

Halim, Abdul., dan Syukriy Abdullah. 2006. Hubungan dan Masalah Keagenan di Pemerintah Daerah: Sebuah Peluang Penelitian Anggaran dan Akuntansi. Jurnal Akuntansi Pemerintah. Vol. 2 (1) 53-64.

Harahap, Sofyan Syahri. 2013. Analisis Kritis Atas Laporan Keuangan. Edisi Pertama. Jakarta: PT. Raja Grafindo Persada.

Mardiasmo.2009, Akuntansi Sektor Publik. Yogyakarta: Andi Offset.

Munawir. 2010. Analisa Laporan Keuangan. Edisi Ke-4. Yogyakarta: Liberty.

Namazi, Mohammad. 2013. Role of the agency theory in implementing management's control. Journal of Accounting and Taxation Vol. 5 (2) $38-47$.

Riswan, dan Yolanda Fatrecia Kesuma.2014. Analisis Laporan Keuangan Sebagai Dasar Dalam Penilaian Kinerja Keuangan Pt. Budi Satria Wahana Motor. Jurnal Akuntansi dan Keuangan Vol. 5 (1) 93-121.

Romney, Marshal B dan Paul John Steinbart. 2015. Accounting Information Sistem. 13 Edition. Jakarta: Salemba Empat.

Standbury. 2003. Accountability to Citizens in the Westminster Model of Government: More Myth Than Reality. Canada: Fraser Institute Digital Publication.

Sugiyono.2016. Metode Penelitian Kuantitatif, Kualitatif, Reseacrch and Development. Bandung: Alfabeta.
Suwardjono. 2013, Teori Akuntansi: Perekayasaan Pelaporan Keuangan. Edisi Ketiga. Yogyakarta: BPFE Yogyakarta.

Zanoni, Andrea Baretta. 2003. Genesis of the Entity Theory: an Analysis of the Scientific Context in the United States of America at the beginning of the XX Century. Accounting History International Conference: 1-20.

Undang-undang Nomor 1 Tahun 2004 tentang Perbendaharaan Negara.Pasal 51 Ayat (2) dan (3).

Undang-undang No. 17 Tahun 2003 tentang Keuangan Negara. Penjelasan Undang-undang Angka 9.

Peraturan Pemerintah Nomor 71 Tahun 2010 tentang Standar Akuntansi Pemerintahan. Lampiran I SAP, PSAP 01.

Peraturan Menteri Keuangan Nomor 177 Tahun 2015 tentang Pedoman Penyusunan dan Penyampaian Laporan Keuangan Kementerian/ Lembaga.

Keputusan Kepala Lembaga Administrasi Negara Nomor: 239/1X/6/8/2003 tentang Perbaikan Pedoman Penyusunan Pelaporan Akuntabilitas Kinerja Instansi Pemerintah. 